\title{
Konsep Soteriologi Menurut Efesus 2:1-10
}

\author{
Desti Samarenna ${ }^{1 *}$ \\ ${ }^{1)}$ Sekolah Tinggi Teologi Internasional Harvest Semarang \\ ${ }^{*}$ Korespodensi Penulis: destisamarenna@gmail.com
}

Diterima:04 Juli 2019 / Direvisi: 23 Sep. 2019 / Disetujui: 06 Nov. 2019

\begin{abstract}
Abstrak
Pemahaman doktrin keselamatan menentukan cara pandang dan hidup setiap orang. Ada beberapa pandangan mengenai keselamatan yang dijelaskan dalam Alkitab. Artikel ini merupakan kajian literatur dengan pendekatan kualitatif terhadap teks Efesus 2:1-10 tentang keselamatan (Soteriology) yang bertujuan untuk memahami keselamatan yang dijelaskan dalam Efesus 2:1-10. Metode yang digunakan adalah kualitatif yang membahas analisis kitab untuk memahami konsep yang ada dalam kitab Efesus 2:1-10 dan penerapannya dalam kehidupan dan pelayanan. Penulis mengambil kesimpulan pertama, memahami posisi manusia yang berdosa oleh karena itu dalam keadaan demikian tidak ada hal yang dapat membuat manusia untuk di selamatkan. Kedua, mengerti keselamatan itu datang dari tangan kasih dan karunia Allah dan bukan hasil pekerjaan manusia.

Kata Kunci: Dosa, Kasih Karunia, Keselamatan, Pekerjaan.
\end{abstract}

\section{Abstract}

Understanding the doctrine of salvation determines the perspective and life of everyone. There are several view about salvation that are explained in the bible. This article is a literature review with a qualitative approach to the text of Ephesians 2:1-10 about salvation (soteriology) which aims to understand safety. The method used is qualitative which discusses tha analysis of the book to understand the concepts that exist in the book of Ephesians 2:1-10 and its applivation in life and service. The author draws the first conclusion, understanding the position of a sinful human being, therefore in such circumstances there is nothing that can 
make human to be saved. Second, understanding that salvation comes from the hands of God's love an grace and is not the work of humans.

Keywords: Sin, Grace, Soteriology, work.

\section{Pendahuluan}

Ajaran tentang keselamatan dikenal dengan istilah soteriologi. Kata soteriologi berasal dari kata Yunani soterion yang berbentuk netral dari nomina feminim soteria yang berarti keselamatan. Soteria pula berasal dari nomina soter berarti penyelamat, juru selamat kalau berbentuk verba berarti menyelamatkan, melepaskan dari bahaya kehancuran. Keselamatan adalah topik yang sering dibicarakan dan tidak pernah berakhir. Ada banyak referensi buku yang membahas tentang keselamatan dan dibicarakan dalam berbagai kajian agama seperti diskusi, seminar yang membahas tentang keselamatan, berbagai pendapat dan asumsi dibangun untuk menemukan arah dan kepastian dari keselamatan tersebut. Hal ini menunjukkan bahwa keselamatan menuntut jawaban dan kepastian. Ajaran keselamatan merupakan pokok bahasan yang luas dalam Alkitab. Masalah itu mencakup seluruh waktu, baik kekekalan di masa lampau maupun kelak. ${ }^{1}$

Topik tentang keselamatan adalah bagian sentral dalam pekabaran Injil. Keselamatan berhubungan dengan menjadi bagian dari umat Allah. Keselamatan adalah refleksi bagi orang percaya yaitu menghasilkan buah dari keselamatan; bukan soal selamat atau tidak selamat; bukan soal kekal tidaknya keselamatan sebab itu merupakan hak prerogatif Allah. ${ }^{2}$ Keselamatan memberikan presuposisi pengetahuan bahwa keselamatan bagi orang berdosa tergantung pada karya Allah yang diketahui oleh Allah sejak kekekalan. ${ }^{3}$ Soteriologi tidak berhenti pada masalah kerinduan keselamatan tetapi akibat dari keselamatan itu, yang terlaksana dalam sejarah manusia. Inti kepercayaan dari kekristenan berbeda dari kepercayaan diluar Kristus. Di luar Kristus berbicara tentang penilaian atas perbuatan manusia di mana hal ini diperhitungkan dosa yang dijabarkan sebagai perbuatan yang menaati

${ }^{1}$ Charles C. Ryrie, Teologi Dasar 2: Panduan Populer untuk Memahami Kebenaran Alkitab (Yogyakarta: Andi Offset, 1991), 15.

${ }^{2}$ Erman S. Saragih, "Soteriologi Hypergrace dalam Perspektif Teologi Marthin Luther dan Alkitab, Teologi Cultivation (2017).

${ }^{3}$ Louis berkhof, Teologi Sistematika 4: Dontrin Keselamatan, penerj. Yudha Thianto (Surabaya: Momentum, 2010), 6. 
hukum Tuhan, dan bila amal seseorang lebih banyak dari dosanya dikatakan orang tersebut masuk sorga sebaliknya bila dosa melebihi amalnya orang tersebut dihukum dan masuk neraka. ${ }^{4}$

Penelitian ini bertujuan untuk menemukan konsep keselamatan orang percaya dalam Efesus 2:1-10. Untuk memahami hal itu, maka penulis akan melakukan tafsir untuk menjawab pertanyaan utama yang sering didengarkan apabila dikaitkan dengan 'posisi' yaitu sejak kapan manusia diselamatkan, dengan cara bagaimana diselamatkan, dan bagaimana mensikapi keselamatan tersebut. Itu sebabnya, pembahasan ini memiliki kepentingan untuk menjawab konsep keselamatan.

\section{Metode Penelitian}

Penelitian ini, merupakan kajian literature teks Alkitab dalam Efesus 2:1-10. Pendekatan yang dilakukan adalah kualitatif. Metode penelitian kualitatif adalah metode yang mencatat hasil amatan secara akurat disamping juga mampu mengungkapkan makna yang dilekatkan oleh subjek penelitian ke dalam pengalaman hidupnya yang ungkapan makna verbal subjektif dan tertulis. ${ }^{5}$ Penelitian kualitatif adalah cara yang penulis tempuh dalam menganalisis masalah konsep keselamatan dalam surat Efesus 2:1-10.

\section{Pembahasan}

\section{Survei Surat Efesus}

Surat Efesus ditulis kira-kira tahun 60-61 M oleh Rasul Paulus selama ia dipenjarakan di Roma (Ef. $1: 1 ; 3: 1 ; 4: 1 ; 6: 20$ ). ${ }^{6}$ Surat ini disampaikan kepada sidang jemaat di Efesus oleh Tikhikus (Ef. 6:21, 22), yang juga digunakan Paulus untuk menyampaikan sepucuk surat kepada orang Kolose (Kol. 4:7-9). Surat kepada orang Kolose dan surat kepada orang Kristen di Efesus ditulis Paulus kira-kira pada waktu yang sama, maka ada sejumlah persamaan antara Efesus dan Kolose.

\footnotetext{
${ }^{4}$ David Eko Setiawan, Konsep Keselamatan dalam Universalisme Ditinjau dari Soteriologi Kristen: Suatu Refleksi Pastoral, Fidei: Jurnal Teologi Sistematika dan Praktika, Vol. 1, No. 2, Desember 2018, 257-261

${ }^{5}$ Norman K Denzein, Yvonna S. Lincoln, Handbook of Qualitative Research, pen., Dariyatno, Badsrus Samsul Fata, Abi, John Rinaldi, peny., Saifuddin Zuhri Qusdy (Yogyakarta: Pustaka Pelajar, 1997), 15.

${ }^{6}$ Alfred Martin, "Efesus," dalam The Wycliffe Bible Commentary, vol., 3, peny., Everett F. Harrison (Malang: Gandum Mas, 2001), 735.
} 
Ada 4 hal yang penting dijelaskan oleh Paulus seperti nasihat tentang materialisme karena Efesus adalah kota yang penting di Asia propinsi dari Romawi dan terkenal dengan perdagangan dan menjadi kota yang kaya dan menganggap kekayaan sebagai hal yang penting. Efesus adalah kota yang indah dengan kuil Artemisnya yang megah, di sana terdapat sebuah batu meteor terkenal yang konon dikirim oleh sang dewi (Kis.19:35). Ratusan pelacur melayani di kuil ini, dan para pedagang setempat menjual berbagai lukisan, patung dan perhiasan dewi Artemis (Kis. 19:23-41). Kota ini juga memiliki teater-teater yang besar, sebuah stadion tempat pertarungan para gladiator, dan perpustakaan-perpustakaan. Paulus berkarya di Efesus sekitar tiga tahun (Kis. 19:10,20:31). Oleh karena itu Paulus menjelaskan tentang 'warisan' sejati yang tersimpan sebagai kekayaan mulia (Ef 1:7, 18; 2:7; 3:8, 16). Dalam Pasal 4:20-24; 5:3-5 dijelaskan mengenai perbuatan moral kemudian mempertentangkan bait dengan kuil dalam pasal 2:21; 4:25-32, menentang praktek demonisme karena Efesus terkenal dengan ilmu gaib dan pengaruh sihir. Satu generasi kemudian, penulis kitab wahyu menulis bahwa orang-orang Kristen Efesus tidak lagi mencintai Kristus (Why. 2:1-7).

\section{Analisis Teks}

Penulis akan menjelaskan konsep keselamatan dalam surat Efesus 2:110 sebagai berikut:

\section{Posisi manusia yang berdosa (Ay. 1-3)}

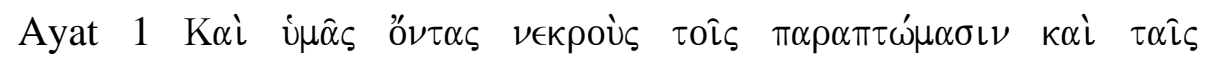

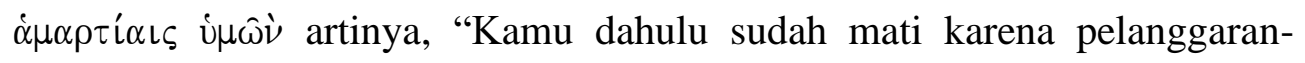
pelanggaran dan dosa-dosamu."

Paulus melukiskan situasi dan cara hidup anggota jemaat yang berasal dari bangsa-bangsa non Yahudi pada waktu dahulu, sebelum mereka bertobat dan menerima Kristus sebagai Tuhan dan Juruselamat mereka.

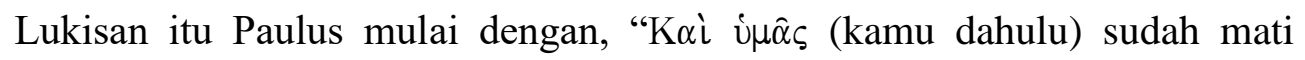
karena pelanggaran-pelanggaran dan dosa-dosamu." Menjelaskan tentang kata $\pi \alpha \rho \alpha \pi \tau \omega \dot{\omega} \alpha \sigma \iota \nu$ berarti false step, transgression, sin dan sejajar dengan itu menggunakan kata $\grave{\alpha} \mu \alpha \rho \tau i \alpha \iota \varsigma$ yang berarti sin: a sinful deed. Keduanya 
berbentuk datif dengan menjadi objek langsung sebagai sebab. ${ }^{7}$ Paulus dalam ayat ini, menjelaskan posisi orang percaya yang sebelumnya sudah berdosa yang dijelaskan dengan kata ő $\nu \tau \alpha \varsigma$ berbentuk partisip akusatif jamak yang berarti waktu atau sebab. Bavinck mengatakan bahwa dosa adalah kesalahan, kecemaran, dan penderitaan sebab dosa mencakup pelanggaran terhadap perjanjian Allah. ${ }^{8}$ Setiap manusia lahir dalam keadaan dosa, tidak karena kesalahannya sendiri, melainkan karena keadaan kongkrit umat manusia yang berupa keadaan berdosa dan yang berdasarkan keadaan awal (dosa Adam). ${ }^{9}$

Paulus, melukiskan mujizat perbuatan Allah, yang dialami juga oleh anggota-anggota jemaat yang berasal dari bangsa-bangsa kafir. Untuk itu ia bertolak dari situasi mereka pada waktu yang silam. Ia katakan, bahwa pada waktu itu mereka mati dalam bahasa Yunani, veкрос (nekros). Kematian itu, menurut dia, disebabkan oleh pelanggaran-pelanggaran dan dosa-dosa mereka Ini berarti secara posisi manusia secara alamiah mati dalam dosa dan pelanggaran. Kata pelanggaran (paraptoma) secara harafiah berarti tergelincir atau jatuh. Paulus menjelaskan kegagalan untuk sampai pada tujuan akibatnya adalah kematian. Esensi dari Kematian adalah hal yang natural yang dialami oleh semua manusia yang telah jatuh dalam dosa. ${ }^{10}$ Teks menjelaskan kata mati dalam Efesus 4:17-18 berarti tidak mengenal Allah dan hidup jauh dari persekutuan dengan Allah. Paulus menekankan tentang tabiat dosa yang memusnahkan kemurnian, cita-cita dan kemauan. ${ }^{11}$ Kematian kekal membawa manusia ke neraka, tempat siksaan dimana mereka akan mengalami keterpisahan jauh dari hadirat Allah untuk selama-

7 Kasus datif juga memiliki berbagai fungsi pertama respek (asosiasi, kepemilikan, lingkungan), kedua obyek tidak langsung, ketiga objek langsung, keempat alat, agen, penyebab atau cara, dan kelima waktu dan ruang. Datif Menyatakan objek tak langsung (pelengkap penyerta/penderita) Ola Tulluan dalam penjelasan Pemakaian kasus-kasus Yunani.

${ }^{8}$ Louis Berkhof, Teologi Sistematika 4: Doktrin Keselamatan, penerj. Yudha Thianto (Surabaya: Momentum, 2010), 12.

${ }^{9}$ Nico Syukur Dister, Teologi Sistematika 2: Ekonomi Keselamatan (Yogyakarta: Kanisius, 2004), 171.

${ }^{10}$ W.E. Vine; Merrill F. Unger, William White "Death," dalam Vine's Expository Dictionaty of Biblical Wordsa: A complete Expository Dictionary of The Old and New Testament in One Volume (New York: Thomas nelson Publisher, 1985), 56.

11 William Barclay, Pemahaman Alkitab setiap hari-hari: Surat-Surat Galatia dan Efesus, pen., S. Wismoady Wahono (Jakarta: BPK Gunung Mulia, 2009), 148. 
lamanya (Wah. 14:11: 20:11-15). Jadi, secara posisi masalah utama manusia setelah kejatuhan adalah kematian, sebagai akibat dari dosa. Kematian itu, disebabkan oleh tindakan mereka menyerahkan hidup dan diri mereka dalam pelanggaran-pelanggaran dan dosa-dosa mereka yang menyimpang dari rencana Allah.

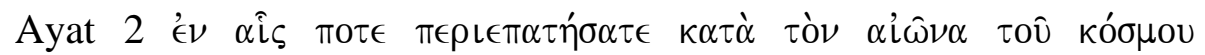

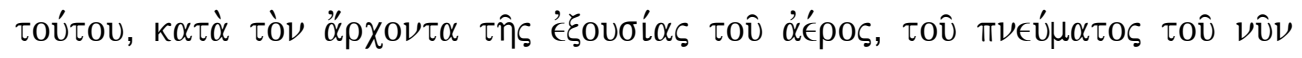

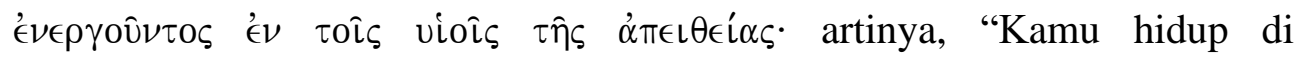
dalamnya, karena kamu mengikuti jalan dunia ini, karena kamu menaati penguasa kerajaan angkasa, yaitu roh yang sekarang sedang bekerja di antara orang-orang durhaka."

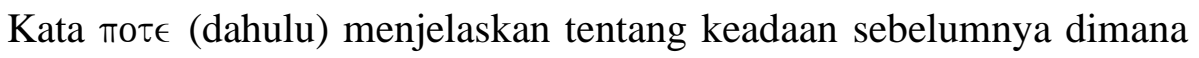
kata $\pi € \rho \iota \epsilon \pi \alpha \tau \eta \dot{\sigma} \sigma \alpha \tau \epsilon$ berbentuk aorist (mengikuti) sistem nilai atau cara hidup, semangat, dunia dan ״’ $\rho \propto \nu \tau \alpha$ (menaati) penguasa atau raja. Hal ini menunjuk kepada suatu gaya hidup atau kebiasaan. ${ }^{12}$ Jadi, manusia di waktu yang lampau atau silam itu memiliki kebiasaan terus menerus hidup dalam dosa mengikuti jalan dunia ini yang menguasai yaitu hawa nafsu dan menurut kehendak daging dalam pengetahuan mereka. Kata oîs viôis $\tau \hat{\eta} \varsigma$ $\dot{\alpha} \pi \epsilon \iota \theta \epsilon i \alpha \varsigma$ artinya anak-anak ketidaktaatan. Manusia disebut demikian karena selalu tidak taat dan terus berdosa. Jadi, penyebab dari perbuatan dosa itu karena pada dasarnya manusia punya keinginan untuk terus menerus berbuat dosa dan membiarkan dirinya dipengaruhi oleh sistem dunia.

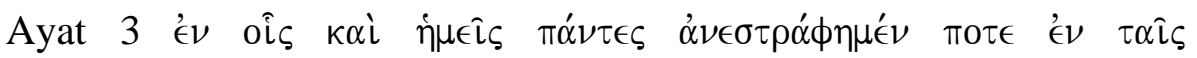

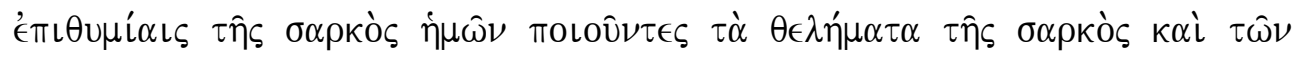

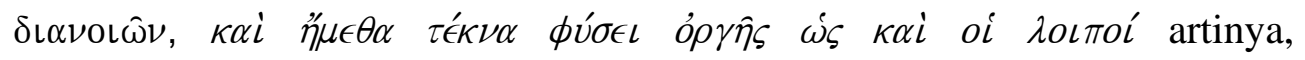
"Sebenarnya dahulu kami semua juga terhitung di antara mereka, ketika kami hidup di dalam hawa nafsu daging dan menuruti kehendak daging dan pikiran kami yang jahat. Pada dasarnya kami adalah orang-orang yang harus dimurkai, sama seperti mereka yang lain."

Bukan orang Kristen kafir saja yang hidup dalam dosa tetapi juga orang-orang Kristen Yahudi juga demikian. Kata é $\mathcal{\nu}$ oi $\varsigma$ berarti diantara mereka, $\dot{\alpha} \nu \epsilon \sigma \tau \alpha \dot{\alpha} \phi \eta \mu \epsilon^{\prime} \nu$ berbentuk aorist pasif berarti kembali berkelakuan

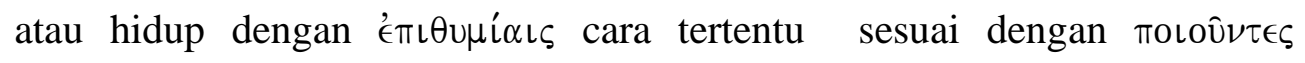

${ }^{12}$ B.F. Drewes, Wilfrid Haubeck, Heinrich von Siebenthal, "Efesus" dalam Kunci Bahasa Yunani Perjanjian Baru (Jakarta: BPK Gunung Mulia, 2002), 159. 
keinginan atau nafsu dengan cara $\tau \grave{\alpha} \theta \in \lambda \eta^{\prime} \mu \alpha \tau \alpha$ macam-macam kehendak daging dan pikiran ada di bawah murka atau hukuman Allah. Paulus menjelaskan bahwa dahulu mereka orang-orang Kristen Yahudi juga hidup diantara orang-orang durhaka. Kata' $\dot{\eta} \mu \epsilon \hat{\iota} \varsigma \pi \alpha \dot{\alpha} \nu \tau \epsilon \varsigma$ (hemeis pantes) berarti 'kami semua'.

Bagian ini menjelaskan bahwa Paulus dan semua orang Kristen Yahudi tidak ada yang terkesuali hidup dalam hawa nafsu daging dan

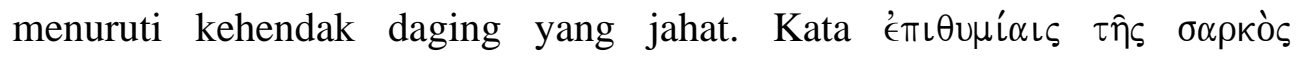
(epithumiai tes sarkos) artinya hawa nafsu daging. ${ }^{13}$ Posisi mereka tidak lebih baik dari orang-orang berdosa yang memiliki hawa nafsu yang bekerja dari dalam diri artinya disadari karena berlangsung dalam pengetahuan mereka, sadar menurut pikiran mereka yang jahat ( $\tau \hat{\omega} \nu \delta\llcorner\alpha \nu \circ \iota \omega \hat{\omega}) .{ }^{14}$ Orang-

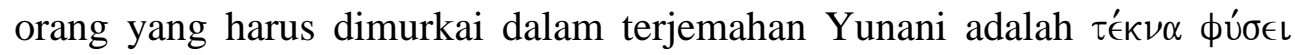
anak-anak murka. ${ }^{15}$ Ini menunjukkan bahwa manusia itu di bawah murka Allah jika meneruskan hidup dan tanpa pertobatan atau percaya kepada Yesus. Secara konteks dalam ayat 1-2 Paulus menggunakan kata 'kamu', yang menjelaskan orang Efesus atau non Yahudi, dan dalam ayat 3 berkata 'kami' dalam konteks orang Yahudi dan mereka yang lain. Penggenapan tindakan penyelamatan Allah yang paling penting yaitu memberi hidup. ${ }^{16}$ Jadi, gambaran ini merupakan penggambaran yang utuh tentang keadaan semua manusia, oleh karena itu Paulus dalam ayat 1-3 melukiskan situasi dan cara hidup anggota jemaat yang berasal dari bangsa-bangsa non Yahudi pada waktu dulu, sebelum mereka bertobat dan menerima Kristus sebagai Tuhan dan Juruselamat. Secara khusus Paulus mengingatkan orang-orang Efesus mengenai posisi mereka dahulu sebagai orang berdosa tetapi hanya karena kasih Allah di dalam Yesus Kristus, kepada manusia diberikan pengampunan. Keselamatan dalam teks ini membahas keyakinan bahwa

${ }^{13}$ Epithumia artinya keinginan, keinginan yang buruk atau jahat, hawa nafsu (Rm. 1:24; Gal 5:24; Erf. 4:22; 2Tim. 2:22).

${ }^{14}$ Dianoia adalah pikiran dan pertimbangan yang sadar dari daging (sark). Dengan menekankan hal tersebut maka Paulus mau menjelaskan bahwa setiap orang atau manusia dalam totalitasnya dengan sadar mengikuti kehendak dagingnya dan pelaksanaan dari kehendaknya itu.

${ }^{15}$ Phusei adalah ungkapan untuk keadaan manusia secara alamiah yaitu kodrat, alam, watak seperti yang berada didalam dan dari dirinya sendiri.

${ }^{16}$ D. Guthrie, "Efesus," dalam Tafsiran Alkitab Masa Kini 3 Matius -Wahyu: Berdasarkan Fakta-Fakta Sejarah Ilmiah dan Alkitabiah, pen., R.P Martini (Jakarta: Yayasan Komunikasi Bina Kasih/OMF, 1999), 584. 
setiap orang percaya telah mengalami penggunaan kuasa Allah yang menetapkan dan menentukan kelepasan dari kehidupan yang dipimpin oleh setan, dunia dan daging.

\section{Tindakan Allah (ay. 4-10)}

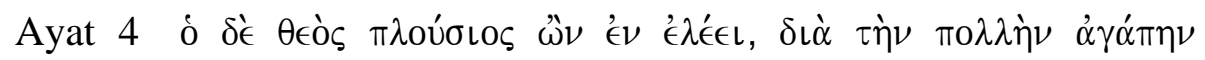

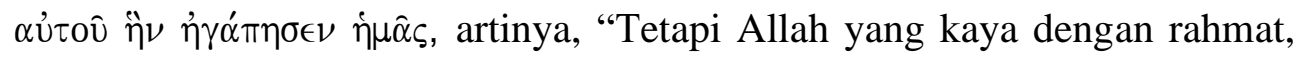
oleh karena kasih-Nya yang besar, yang dilimpahkan-Nya kepada kita.”

Dalam teks ini Paulus menjelaskan ò d’e $\theta \epsilon o ̀ \varsigma$ (tetapi Allah). Ini menjelaskan apa yang Allah lakukan bagi semua orang. ${ }^{17}$ Ini menunjukkan

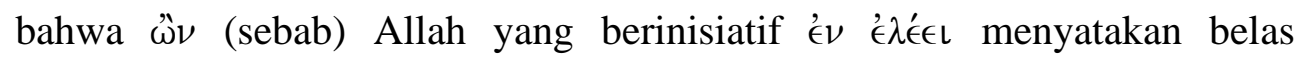

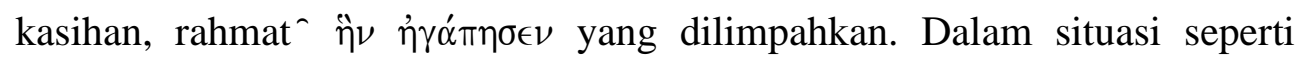
yang digambarkan di atas itu Allah bertindak. Ia tidak membiarkan manusia binasa dalam dosanya. Ia menyelamatkannya dari kematianNya. Katá d’́ de dalam ayat ini berarti tetapi, suatu pertentangan dengan teks sebelumnya. Paulus dalam teks ini menjelaskan penebusan dan keselamatan tentang Allah yang rahmani dan rahimi Allah seperti yang telah dikatakan di atas

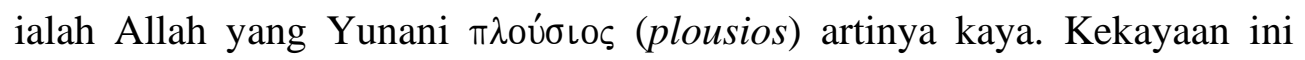

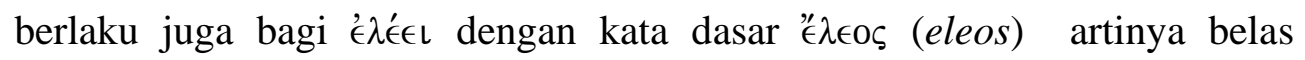
kasihan atau rahmat. Jadi rahmat itu diberikan berdasarkan kasih Allah yang besar. Roma 11:30-32 menjelaskan, "Sebab sama seperti kamu dahulu tidak taat kepada Allah, tetapi sekarang beroleh kemurahan oleh ketidaktaatan mereka, demikian juga mereka sekarang tidak taat, supaya oleh kemurahan yang telah kamu peroleh, mereka juga akan beroleh kemurahan. Sebab Allah telah mengurung semua orang dalam ketidaktaatan, supaya Ia dapat menunjukkan kemurahan-Nya atas mereka semua."

Rahmat Allah begitu besar sehingga dapat menyelamatkan orang-

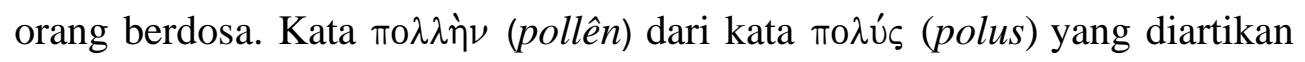
besar. Kasih yang besar ini Ia limpahkan kepada kita. Dalam bahasa Yunani

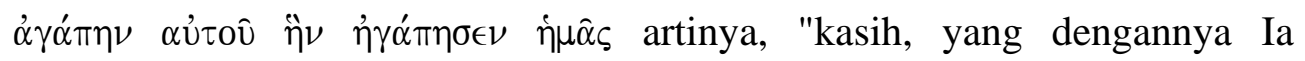
mengasihi kita." Dengan menyebut dua kali kata kasih yaitu agapâ̂ dari Allah itu, maka Paulus menekankan besarnya kasih itu dan pikiran bahwa kasih tersebut dilimpahkan kepada orang berdosa. Jadi, kasih Allah yang

${ }^{17}$ Robert G. Bratcher, Surat Paulus Kepada Jemaat di Efesus (Jakarta: LAI: Yayasan Karunia Bakti Budaya Indonesia, 2013), 42. 
besar ialah kasih yang di nyatakan dalam Kristus, berdasarkan kematian dan kebangkitanNya.

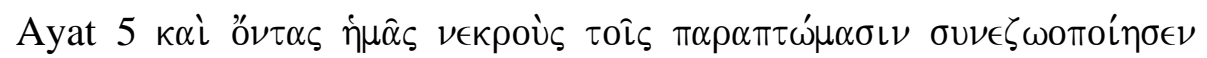

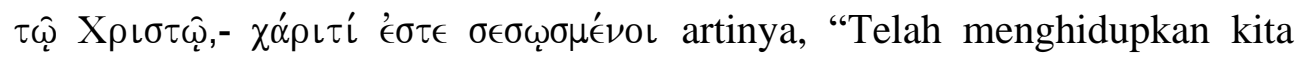
bersama-sama dengan Kristus, sekalipun kita telah mati oleh kesalahankesalahan kita oleh kasih karunia kamu diselamatkan."

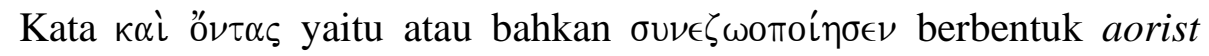
datif menghidupkan bersama-sama dengan Kristus. Ini semua sama seperti yang dialami oleh Yesus Kristus. ${ }^{18}$ Ayat ini, seperti yang dikatakan di atas, menjangkau kembali kepada ayat 1. Diterjemahkan, "Juga kita, sekalipun kita telah mati karena pelanggaran-pelanggaran kita (Allah) telah menghidupkan kita bersama-sama dengan Kristus oleh kasih karunia kamu diselamatkan." Juga kita berbicara tentang seluruh jemaat baik orang-orang Kristen, Yahudi maupun orang-orang Kristen non Yahudi, mereka semua secara posisi telah mati karena pelanggaran-pelanggaran mereka telah Allah hidupkan bersama-sama dengan Kristus. Tetapi 'telah dihidupkan', berarti kehidupan masa kini memiliki nilai. Manusia yang sudah terpisah dari Allah akan mengalami kematian tetapi karena percaya kepada Yesus akan mengalami kehidupan yang berlanjut dpada hidup akan datang waktu Dia dibangkitkan. Hal ini memberikan pemahaman bahwa ketika dihidupkan bersama Kristus, posisi sudah dilahirbarukan. Kata 'kita' artinya seluruh jemaat, baik orang-orang Kristen-Yahudi maupun orang-orang Kristen-non Yahudi. Mereka semua, yang "'telah mati karena pelanggaran-pelanggaran mereka' telah Allah hidupkan bersama-sama dengan Kristus. Jadi ada persatuan antara Kristus dengan orang-orang pilihan, menyebabkan apa yang dialami oleh Kristus dialami orang percaya.

Kata $\chi \alpha \dot{\alpha} \rho \iota \iota$ dari kata $\chi \alpha \dot{\alpha} \rho \iota \varsigma$ yang berarti rahmat, keanggunan, daya tarik dalam bahasa Inggris menggunakan kata grace artinya anugerah. Ada beberapa pengertian tentang anugerah, pertama, anugerah adalah atribut Allah, salah satu kesempurnaan ilahi. Kedua, istilah anugerah dipakai untuk menunjukkan provisi obyektif yang dibuat Allah di dalam Kristus bagi keselamatan manusia. Ketiga, kata anugerah dipakai untuk menunjuk kehendak Allah. ${ }^{19}$ Kata $\sigma \in \sigma \omega \sigma \mu \epsilon \in \mathcal{\nu} \nu$ เ berbentuk partisif perfek pasif dari kata

\footnotetext{
${ }^{18}$ Kata $\sigma \cup \nu \in \zeta \omega 0 \pi o i ́ \eta \sigma \in \nu$ dalam Bible Work 6

${ }^{19}$ Berkhof, Teologi Sistematika 4: Doktrin Keselamatan, 33.
} 
$\sigma \omega ́ \zeta \omega$ artinya rescue, liberate, keep from harm, heal, preserve, yang berarti Ia menyelamatkan. ${ }^{20}$ Keselamatan itu telah berlangsung dan tetap berlangsung sampai sekarang. Mereka telah diselamatkan dan tetap menjadi orang yang diselamatkan. Keselamatan dalam konteks berbicara dari pembebasan keadaan manusia yang dijelaskan dalam ayat 1-3. Ayat keempat dan keenam dalam teks ini Paulus menjelasan bahwa orang-orang yang mati adalah orang-orang yang tidak melihat Allah dan tidak mau mengakui adanya Allah yang begitu penuh kasih karunia di dalam Kristus. Begitu besar kasih Allah kepada orang-orang berdosa, sehingga anakNya sendiri Yesus Kristus, Ia serahkan ke dalam maut untuk keselamatan mereka. Alur pemikiran Paulus menjelaskan bahwa murka dan kasih Allah itu berjalan bersama karena disitu terletak kebesaran kasih Allah. Hal itu dinyatakan kepada Paulus oleh Yesus Kristus. Yesus Kristus ini telah memasuki kematian, supaya dengan jalan itu orang percaya boleh dihidupkan kembali.

Paulus memahami bahwa Jemaat di Efesus memahami penyelamatan atau penebusan itu telah berlangsung dan bahwa mereka sendiri mendapat

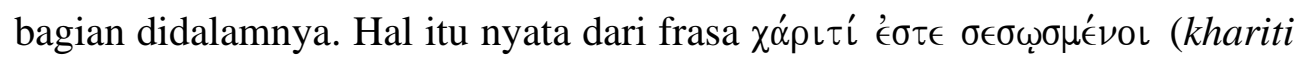
este sesôsmenoi) karena kasih karunia kamu diselamatkan. Berbentuk kalimat perfek este sesôsmenoi menyatakan bahwa keselamatan itu telah berlangsung dan tetap berlangsung sampai sekarang. Mereka telah diselamatkan dan tetap menjadi orang-orang yang diselamatkan. Hal itu mungkin karena kasih-karunia Allah seperti yang dijelaskan dalam Efesus 1:2, "Kasih karunia dan damai sejahtera dari Allah, Bapa kita dan dari Tuhan Yesus Kristus menyertai kamu." Paulus menjelaskan seluruh pekerjaan Kristus yang tidak boleh dilupakan. Allah melakukannya dalam hubungannya dengan Kristus. Kolose 3:3, "Sebab kamu telah mati dan hidupmu tersembunyi bersama dengan Kristus di dalam Allah." Jadi, penyelamatan terjadi dari sisi Allah berdasarkan anugerah yaitu menyatakan kehendakNya.

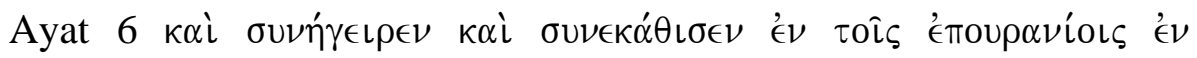

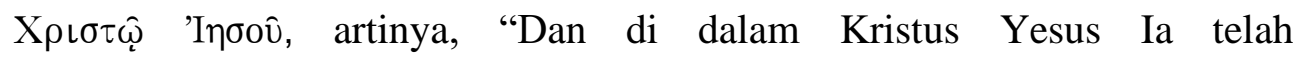
membangkitkan kita juga dan memberikan tempat bersama-sama dengan Dia di sorga."

\footnotetext{
${ }^{20}$ Kata $\sigma \omega \varrho \zeta \zeta \omega$ dalam Bible Work 6.
} 
Paulus mengekspresikan keyakinannya bahwa Allah akan menyelesaikan apa yang telah ia mulai dalam jemaat Filipi. Kata $\sigma u \nu \eta ́ \gamma \epsilon \iota \rho \epsilon \nu$ berbentuk aorist indikatif yang berarti menyebabkan seseorang bangkit

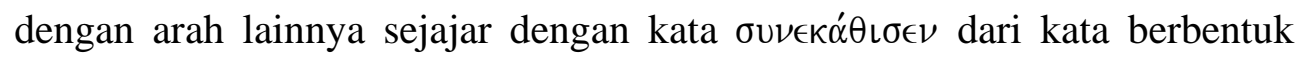
aorist aktif dari kata ' moupóvı dalam ayat ini adalah sejajar dengan gagasan yang terkandung dalam 1:19. Di situ dikatakan tentang kuasa Allah yang hebat, yang dikerjakanNya di dalam Kristus, bahwa hal itu Ia buat untuk jemaatNya. Tuhan Allah membangkitkan Dia dari antara orang mati dan mendudukkan Dia di sebelah kananNya di sorga. Hal itu berarti, mereka juga dibangkitkan dari antara orang mati dan ditempatkan bersama-sama dengan Kristus di sorga. Tiga kali Paulus memakai sun, yang berarti bersama-sama. Dalam Teks Yunani terdapat tiga kata yang didahului dengan kata sun, yaitu:

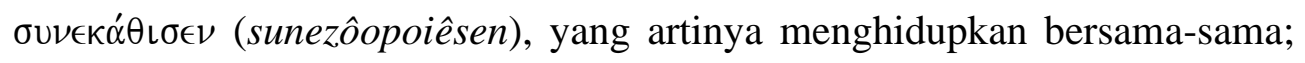

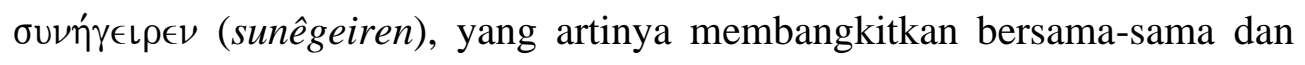
$\sigma \cup \nu \in \kappa \alpha ́ \theta\llcorner\sigma \in \nu$ (sunekathisen), yang artinya menempatkan bersama-sama, tetapi cara pemakaian ketiganya tidak sama. Dalam ayat 5 Paulus tidak memakai en khristô (dalam Kristus), tetapi lebih umum tô khristô (dengan Kristus). Ketiga ungkapan ini dengan jelas mengatakan, bahwa semuanya adalah karya Allah dalam Kristus untuk anggota-anggota jemaat. Karena itu pada bersama-sama yang pertama mereka diperingatkan, oleh kasih-karunia kamu diselamatkan. Bersama-sama yang kedua dan ketiga itu menjelaskan kata bersama-sama yang pertama. Mereka dibangkitkan bersama-sama dengan Kristus, karena itu mereka mendapat bagian dalam hidupNya. Mereka ditempatkan bersama-sama dengan Dia di sorga, karena itu, ada tiga kata kerja untuk menyebutkan pekerjaan Allah dalam Kristus. Pertama, Allah telah menghidupkan kita bersama-sama dengan Kristus (ay. 5); kedua, di dalam Yesus Kristus Ia telah membangkitkan kita juga (ay. 6a); dan ketiga, Ia memberikan tempat bersama-sama dengan Dia di surga (ay. 6b). ini merujuk kepada tiga peristiwa yang berurutan dalam karya Kristus yang menyelamatkan, yang disebut kebangkitan, kenaikan dan kedudukan. ${ }^{22}$

\footnotetext{
${ }^{21}$ Aorist Indikatif itu berarti suatu tindakan kepastian yang telah terjadi dimasa lampau dengan tidak membahas lebih lanjut tentang aspeknya

${ }^{22}$ John R.W. Scott, Efesus (Jakarta: Yayasan Komunikasi Bina Kasih/OMF, 2003), 76.
} 


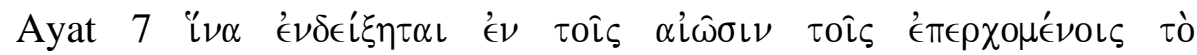

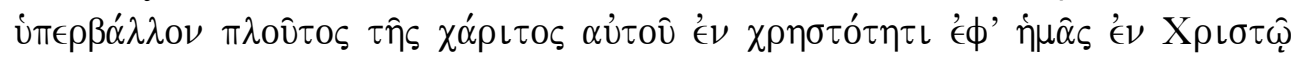

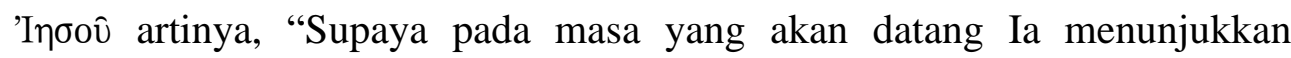
kepada kita kekayaan kasih karunia-Nya yang melimpah-limpah sesuai dengan kebaikan-Nya terhadap kita dalam Kristus Yesus."

Paulus menjelaskan tujuannya, "Supaya pada masa yang akan datang Ia menunjukkan kekayaan yang melimpah-limpah dari kasih-karuniaNya kepada kita dalam Kristus Yesus." Itulah maksud dan tujuan yang utama dari pekerjaan Allah. Ia berasal dari Allah dan kembali kepada-Nya. ¿ $v \alpha$ $\epsilon^{\prime} \nu \delta \epsilon \hat{\imath} \xi \eta \tau \alpha$ (ina endeixêtai) artinya supaya ia menunjukkan. ${ }^{23}$ Untuk masa akan datang, akan ditunjukkan "kekayaan yang melimpah-limpah dari kasihkarunia-Nya." Tuhan Allah menyelamatkan manusia dari kematiannya yang dijelaskan dalam ayat 1 dan 3 kemudian membawanya kepada kemuliaan supaya manusia dari zaman ke zaman melihat pekerjaan Allah yang Ia kerjakan melalui AnakNya, Yesus Kristus. Paulus disini menggunakan kata ploutos yang artinya kekayaan, dan kemuliaan dalam bagian ini adalah kharis yang artinya kasih karunia Allah, yaitu kebaikanNya kepada orang percaya di dalam Yesus Kristus. Allah melakukan semua itu kembali untuk kemulianNya. Frasa “ Kebaikan-Nya terhadap kita dalam Kristus Yesus".

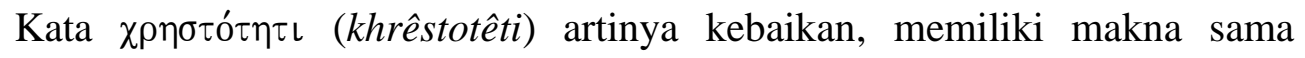
artinya dengan kasih-karunia Allah. Ini menunjukkan bahwa kebaikan-Nya kepada kita dalam Yesus tidak sekadar kata-kata tentang anugerah atau kasih-karunia yang mengampuni dosa melainkan kebaikan Allah, yang tidak diharapkan oleh manusia yang berdosa, tetapi yang dilimpahkan atas mereka eph hêmas dalam Kristus, artinya dalam persekutuan dengan Dia, oleh pekerjaan-Nya. Paulus di sini memakai kata ploutos artinya kekayaan, yang memperkuat pengertian huperballon artinya melebihi ukuran, melimpahlimpah. Pekerjaan Allah selamanya kaya dan mulia. Dalam nas, kekayaan dan kemuliaan itu mengenai kharis artinya kasih-karunia Allah. Dalam nas ini Paulus dengan tegas mengakui pekerjaan Allah yang mencakupi seluruh kosmos. khrêstotês artinya kebaikan Allah kepada jemaat ialah tempat, dari mana terang pekerjaan Allah menyinarkan cahayanya ke atas perspektif-

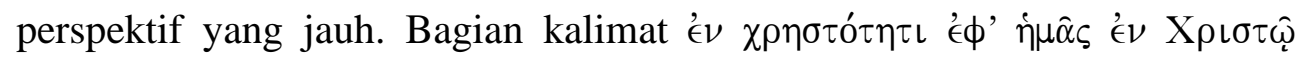

${ }^{23}$ Kata endeixêtai berbentuk aorist aktif berasal dari kata endeiknumi dan berarti menunjukkan, mendemonstrasikan, begitu rupa, sehingga nyata, kepada tiap-tiap orang. 


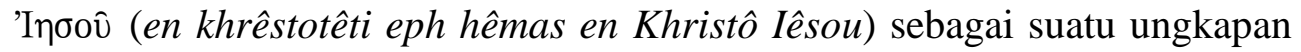
dan erat berhubungan dengan bagian kalimat yang mendahuluinya yaitu kasih-karunia Allah, yang diakui sekarang dalam iman, sekali kelak akan tampak dalam kekayaannya yang melimpah-limpah kepada tiap-tiap orang dalam kebaikan kepada kita dalam Kristus Yesus.

Jadi, ayat 4-7 dihidupkan kembali atau dilahirkan kembali dan memiliki posisi yang sangat terkait dengan Kristusdengan pembaharuan hidup dan kewarganegaraan surga. Orang percaya tidak lagi berhubungan atau bersekutu dengan kuasa-kuasa dunia dan pergumulan kosmik tetapi sudah memiliki akses kepada Tuhan.

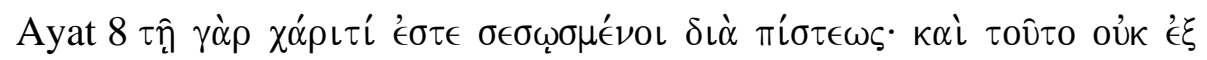
ú $\omega \hat{\nu} \nu, \theta \in o \hat{v}$ tò $\delta \hat{\rho} \rho \nu$ " artinya, "Sebab karena kasih karunia kamu diselamatkan oleh iman; itu bukan hasil usahamu, tetapi pemberian Allah."

Paulus memulai dengan kata $\gamma \grave{\alpha} \rho$ (gar) yang menghubungkan ayat ini dengan kata $\pi \alpha \rho \alpha \pi \tau \omega ́ \mu \alpha \sigma \iota \nu$ dari kata $\pi \alpha \rho \alpha ́ \pi \tau \omega \mu \alpha$ (paraptoma) dalam ayat 5. Paulus mau menjelaskan bahwa apa yang ia tuliskan dalam ayat 5 adalah benar. Mereka diselamatkan karena kasih karunia Allah. Kemudian Paulus menambahkan oleh iman. Dalam teks, iman adalah alat untuk memperoleh keselamatan atau kasih karunia Allah. Iman dalam arti ini banyak dapati dalam surat-surat Paulus. Iman adalah terjemahan dari kata Yunani pistis (kata benda) dan pisteuo (kata kerja) yang berarti percaya, kepastian, yakin kepada seseorang atau apa yang dikatakannya. Di dalam Kolose 2:12 sebagai alat yang menerima kebangkitan dalam Kristus, dalam Efesus 3:17 sebagai jalan yang membawa Kristus masuk dan berdiam di dalam hati anggota-anggota jemaat. Roma 3:22 sebagai jalan yang memimpin kepada kebenaran. Filipi 3:9; Galatia 2:16 sebagai jalan yang memimpin kepada kebenaran. Galatia 3:20 sebagai jalan yang memimpin kepada status anak. Perjanjian Baru menjelaskan iman dengan percaya kepada perkataan, penebusan, Dia adalah Tuhan dan Juruselamat dan mepercayakan diri kepadaNya.

Dalam bahasa Yunani kata 'itu' menunjuk kepada 'ini', berbentuk netral sedangkan iman berbentuk feminin. Jadi kata itu, tidak menunjuk kepada iman tetapi kepada karena kasih karunia kamu diselamatkan oleh iman. Secara posisi, keselamatan itu pemberian Allah atau anugerah Allah. Kasih karunia Allah merupakan sumber keselamatan Kasih karuni adalah 
pemberian Allah yang diberikan kepada manusia yang memang tidak layak menerima. Siapa yang menerima, secara konteks 'kamu', berarti tiap-tiap

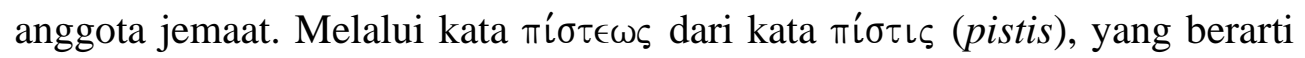
iman, Paulus hendak menunjukkan segi subyektifnya, di mana ia

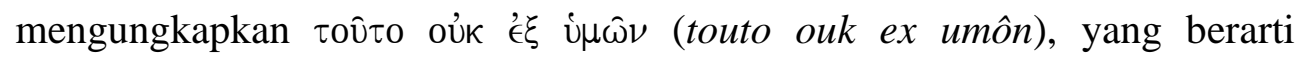
bahwa semua yang didapat adalah bukan hasil usahamu itu ( $\theta \epsilon o \hat{v}$ tò $\delta \hat{\omega} \rho o \nu)$. Keselamatan itu tidak ada unsur usaha dari manusia tetapi dari sisi Allah diberikan karena posisi manusia dimasa lampau telah berdosa dan sekali untuk selamanya artinya tidak terulang lagi. Roma 5:1-2 menjelaskan, "Sebab itu kita yang dibenarkan oleh iman, kita hidup dalam damai sejahtera dengan Allah, oleh karena Tuhan kita Yesus Kristus. Oleh dia kita juga beroleh jalan masuk oleh iman kepada kasih karunia ini. Di dalam kasih karunia ini kita berdiri dan kita bermegah dalam akan menerima kemuliaan Allah." Kematian Kristus di kayu salib bukan memberikan kebenaran kepada orang-orang yang hidup dibawah hukum taurat (Gal.2:16), melainkan kepada siapapun yang percaya kepada Tuhan Yesus (2Kor. 5:21). Jadi, Alkitab menjelaskan bahwa manusia tanggungjawab untuk percaya, dan anugerah itu bisa diterima hanya dengan percaya kepada Tuhan Yesus.

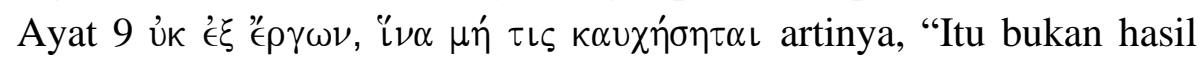
pekerjaanmu, jangan ada orang yang memegahkan diri.”

Paulus melanjutkan, itu bukan pekerjaanmu. Menekankan bahwa pekerjaan merupakan hasil atau buah dari keselamatan, bukan penyebabnya. Pembenaran tidak berhubungan dengan tingkah laku. Ungkapan, "Jangan kamu memegahkan diri" artinya jangan menyangka bahwa pekerjaan yang dikerjakan di dalam atau di luar jemaat itu adalah suatu jasa, dan bahwa karena itu keselamatan dapat diperoleh berdasarkan jasa-jasa, ataupun berdasarkan kesalehan sehingga mengharapkan segala sesuatu dari dirimu sendiri. Semuanya adalah kasih-karunia Allah. Kata yang digunakan untuk menjelaskan adalah kharis artinya kasih karunia bukan pistis artinya iman dan itu adalah dôron artinya pemberian Allah. Paulus memberikan tekanan pada kasih karunia karena secara posisi jemaat Efesus meyakini bahwa keselamatan itu sebagai akibat dari pekerjaan. Kata ' $\epsilon \xi$ ' $€ \rho \gamma \omega \nu$ dalam teks ini menjelaskan pekerjaan atau perbuatan yang salah menafsirkan hukum Taurat dan yang karena itu, membanggakan diri sendiri sebagai prestasi manusia. Ayat 10 ini Paulus menjelaskan erga agatha sebagai lawan dari 
erga nomou maka Paulus menegaskan itu bukan pekerjaan kamu itu adalah pemberian Allah. ${ }^{24}$ Ungkapan memegahkan diri dalam arti usaha membangun diri sendiri, yang didasarkan atas kekuatan atau prestasi baik dalam pengetahuan, pekerjaan. Paulus mau menekankan kepada jemaat bahwa pekerjaan yang dikerjakan di dalam atau di luar jemaat itu adalah suatu jasa, oleh karena itu keselamatan diperoleh tidak bisa karena jasa atau usaha pekerjaaan maupun kesalehan melakukan hukum Taurat semua itu adalah kasih karunia (kharis) sebagai pemberian (doron) dari Allah. Jadi, pembenaran tidak berhubungan dengan tingkah laku yang benar berdasarkan usaha yang dilakukan tetapi karya pengorbanan yesus yang menjadikan benar secara posisi.

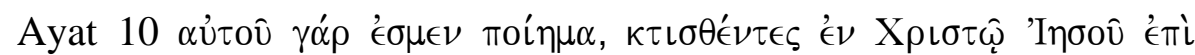

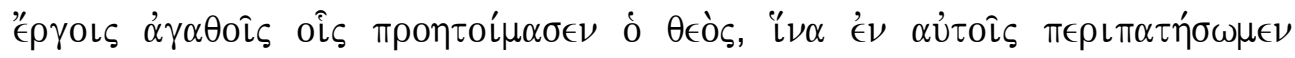
artinya, "Karena kita ini buatan Allah, diciptakan dalam Kristus Yesus untuk melakukan pekerjaan baik, yang dipersiapkan Allah sebelumnya. Ia mau, supaya kita hidup di dalamnya."

Paulus menjelaskan bahwa manusia adalah 'buatan Allah yang diciptakan', sehingga secara posisi tidak ada usaha untuk mendapatkan keselamatan. Secara konteks tindakan penyelamatan Allah dilakukan karena rahmat, kasih (ay. 4), kasih karunia (ay. 5, 8) dan kebaikanNya (ay.7). Semua itu terdapat dalam diri Allah. Keselamatan hanya berasal dari Allah karena itu keyakinan keselamatan adalah sebuah proses seumur hidup supaya kita berbuat baik (ay. 10). Paulus memberikan penjelasan bahwa anggota-anggota jemaat yang dibangkitkan dari antara orang mati ditempatkan bersama-sama dengan Kristus di sorga dengan status ciptaan

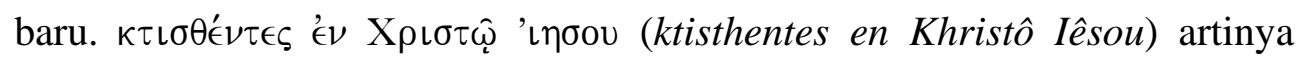

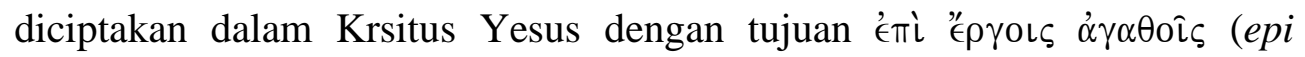
ergois agathois) yaitu melakukan pekerjaan baik. ${ }^{25}$ Pekerjaan baik itu sudah dipersiapkan Allah sebelumnya dan Ia ingin supaya orang percaya hidup atau berjalan di dalamnya. Pemulihan anuerah dari Allah bukan hanya menyelamatkan tetapi juga mengubahkan. Sasaran keselamatan dalam kehidupan ini adalah memiliki akses untuk memperoleh kuasa yang berdasarkan kasih karunia sehingga memiliki identitas yang baru. Kelahiran

\footnotetext{
${ }^{24}$ JL Ch Abuneno, Surat Efesus (Jakarta: BPK Gunung Mulia, 1971), 44-59.

25 €́ $\pi \iota$ Berbentuk datif untuk menyatakan tujuan
} 
baru atau dilahirkan baru harus dialami oleh setiap orang. Tujuannya adalah namanya dicatat dalam kitab kehidupan dan dimateraikan oleh Roh Kudus yang akan memampukan untuk melakukan apa yang Allah kehendaki karena perbuatan baik asalnya dari Allah sendiri. Orang yang menerima Kristus secara pribadi mendapatkan hidup yang kekal. Ayat kesepuluh ditujukan bagi mereka anak-anak yang telah dihidupkan di dalam Kristus, yaitu kepada anak-anak ketaatan. Pewahyuan dari Allah adalah suatu proses dalam sejarah manusia, paham keselamatan memegang unsur yang utama. Pada akhirnya, konsep keselamatan yang dijelaskan Paulus memberikan pemahaman yang komprehensif bahwa keselamatan memiliki nilai tertinggi dalam menjalani hidup yang berkualitas di dunia ini dan juga berlanjut kepada kekekalan.

\section{Kesimpulan}

Konsep keselamatan yang dijelaskan dalam surat Efesus 2:1-10 menjelaskan dan menguraikan keadaan manusia: pertama, posisi manusia yang berdosa (Ay. 1-3) dan kedua, tindakan Allah (Ay. 4-10). Posisi manusia yang berdosa terjadi karena ketidakpercayaan. Hal inilah yang menyebabkan sampai hari ini setiap orang yang tidak percaya kepada Tuhan membiarkan dirinya bersekutu dengan Iblis yang menghasilkan kehidupan yang mengarah kepada keadaan yang terus menerus hidup dalam pelanggaran-pelanggaran, dosa-dosa dalam pengetahuan mereka dan berakhir dengan kematian. Tindakan Allah dalam memanusia itu dengan cara menjadi kutuk dikayu salib dan mencurahkan darahnya sekali untuk selama-lamanya. Setiap orang yang menerima naugerah keselamatan itu hanya dengan percaya kepada Yesus sebagai Tuhan dan Juruselamat. Kemudian setiap orang yang percaya yang memiliki pemahaman konsep keselamatan yang benar akan menentukan cara menjalani hidup yang berkualitas. Orang percaya ditarik dari pelanggaran-pelanggaran melalui anugerah penebusan dalam Kristus di selamatkan untuk melakukan perbuatan baik, selamat karena pekerjaan Allah. Hanya melalui Yesus saja orang diselamatkan. "Sebab di seluruh dunia di antara manusia tidak ada seorang lain pun yang mendapat kekuasaan dari Allah untuk menyelamatkan kita." (BIS Kis. 4:12). Jadi, manusia pada dasarnya berdosa dan harus beriman dulu karena iman yang menghasilkan pertobatan yang membawa kepada anugerah keselamatan yang terjadi saat kelahiran baru, 
kemudian diperlengkapi dengan perbuatan baik sebagai tanda keselamatan sehingga nama Tuhan dipermuliakan dalam hidup dan pelayanan dalam dunia ini.

\section{Daftar Pustaka}

Abineno, JL Ch. Surat Efesus. Jakarta: BPK Gunung Mulia. 1971

Barclay, William. Pemahaman Alkitab setiap hari-hari: Surat-surat Galatia dan Efesus. Penerjemah S. Wismoady Wahono. Jakarta: BPK Gunung Mulia, 2009.

Berkhof, Louis. Teologi Sistematika 4: Doktrin Keselamatan. Penerjemah Yudha Thianto. Surabaya: Momentum, 2010.

Bible Work 6.

Bratcher, Robert G. Surat Paulus Kepada Jemaat di Efesus. Jakarta: LAI: Yayasan Karunia Bakti Budaya Indonesia, 2013.

Dister, Nico Syukur. Teologi Sistematika 2: Ekonomi Keselamatan. Yogyakarta: Kanisius, 2004.

Denzein, Norman K. Yvonna S. Lincoln. Handbook of Qualitative Research. Penerjemah Dariyatno, Badsrus Samsul Fata, Abi, John Rinaldi. Penyunting Saifuddin Zuhri Qusdy. Yogyakarta: Pustaka Pelajar, 1997.

Drewes, B.F. Wilfrid Haubeck, Heinrich von Siebenthal. "Efesus." Dalam Kunci Bahasa Yunani Perjanjian Baru. Jakarta: BPK Gunung Mulia, 2002.

Guthrie, D. "Efesus.” Dalam Tafsiran Alkitab Masa Kini 3 Matius -Wahyu: Berdasarkan Fakta-Fakta Sejarah Ilmiah dan Alkitabiah. Penerjemah R.P Martini. Jakarta: Yayasan Komunikasi Bina Kasih/OMF, 1999.

Martin, Alfred "Efesus." Dalam The Wycliffe Bible Commentary. Volume 3. Pentunting Everett F. Harrison. Malang: Gandum Mas 2001.

Ryrie, Charles C. 1991. Teologi Dasar 2: Panduan Populer untuk meemahami Kebenaran Alkitab. Yogyakarta: Andi Offset.

Scott, John R.W. Efesus. Jakarta: Yayasan Komunikasi Bina Kasih/OMF, 2003.

Setiawan, David Eko,. "Konsep Keselamatan dalam Universalisme Ditinjau dari Soteriologi Kristen: Suatu Refleksi Pastoral", Fidei: Jurnal Teologi Sistematika dan Praktika, Vol. 1, No. 2, 2018. 
Vine W.E, Merrill F. Unger (et. All). "Death.” Dalam Vine's Expository Dictionaty of Biblical Wordsa: A complete Expository Dictionary of The Old and New Testament In One Volume (New York: Thomas nelson Publisher), 1985.

Saragih, Erman S. "Soteriologi Hypergrace dalam Perspektif Teologi Marthin Luther dan Alkitab, Teologi Cultivation, 2017. 